\title{
4. Irish urban policy: from benign neglect to national strategic planning
}

Paula Russell and Brendan Williams

\section{INTRODUCTION}

Historically, Ireland has never had an explicit, overarching urban policy, a gap which has often been identified, but has never been filled (Bannon 2007; Moore-Cherry and Tomaney 2019). There have been many urban-related policies, including urban regeneration policies, housing policies and planning policies, that have helped to shape the complexion of Irish cities and towns over the past 35 years, but there has never been a Department or a Minister for urban development. The National Planning Framework: Project Ireland 2040 (NPF) adopted in 2018 does however for the first time offer a comprehensive iteration of urban policy. It outlines a broad vision for Irish urban development and a national framework for such development. The ambition for urban areas is indicated by ten specific urban-related national policy objectives which aim to create stronger urban places. This is a significant development in Irish urban policy which heretofore might be described as consisting of a myriad of indirect, largely market-driven, policy interventions which have a distinct impact on urban areas.

The urbanisation of the Irish population has ensured that there is now a greater emphasis on policy which impacts on urban areas, and policy has moved from the benign neglect of urban issues to a recognition of the role of Irish cities and towns in Ireland's ongoing economic development. Ireland is a relatively small island country with a population of 4.76 million in the Republic of Ireland; the urban population is now larger than it has ever been and for the first time over half of the population, or nearly 2.4 million people, live in cities or large towns of at least 10000 people. However, the urban structure remains weak and focused on Dublin and the south and east of the country (Government of Ireland 2018a). Dublin is the only metropolitan area with a population of over one million, while the regional cities of Cork and Galway have been growing but at a relatively slow pace, with Cork and its population of 208669 being the only city with over 100000 inhabitants in the 
national settlement system (CSO 2017). The NPF together with the National Development Plan (NDP) (Government of Ireland 2018b) and a number of newly introduced funding instruments and institutional structures are currently shaping urban policy, and exemplify this enhanced urban policy focus. Given the importance of the NPF, a more detailed overview of its urban content and role is provided in the penultimate section of the chapter which focuses on specific policies. The three key urban challenges reflected in the policy of the NPF and other urban-related policies are (1) tackling the current housing crisis, (2) accommodating continuing population growth in a sustainable manner through the intensification of development in attractive liveable urban areas, and (3) dealing with the challenges of climate change.

Historically, the Irish political class has adopted a rural mindset; contributory factors are argued to include a cultural antipathy to cities due to colonial associations, and the presence of only one large or metropolitan city (Moore-Cherry and Tomaney 2019). The modern Irish planning system was established by the Planning and Development Act in 1963 as part of a recognition of the need to develop a more modern urban society. It formed part of a radical change from protectionism to an outward-looking export-based economy coupled with inward investment. There was no attempt at this time to introduce a national urban policy, although as the 1960s progressed the government commissioned a number of advisory plans for the development of urban areas (Bannon and Grier 1998). The predominant spatial development model of the late 1950 s to the 1970s can best be described as low-density suburbanisation and inner-city decline.

During the 1970s there was a recognition both of the challenges of the regional imbalances of the Irish urban system and of the evidence of sprawl and congestion in Dublin (NESC 1979). Recommendations were made regarding the need to reform and rationalise the urban management and planning policy systems, and the need to introduce the recommendations which had been made in the Kenny Report whereby planning gain could be recouped from ongoing speculative land development processes (NESC 1981). All the issues involved complex political commitment and decision making and little urban policy reform was actually enacted.

The 1980s saw the first concerted attention on inner-city areas, and a series of market-oriented, entrepreneurial policies were introduced by central government, firstly in Dublin and subsequently in Ireland's other cities and towns. This approach continued and was intensified throughout the 1990s as unprecedented growth occurred in the Irish economy. More recently, from 2000 to 2019 the Irish urban development experience presents a clear example of a development-led process which is highly cyclical with potential for major corrections and accompanying negative social and economic consequences. The period of boom from 2000 to 2007 in the Irish economy was followed 
by a major financial crisis and correction from 2008 to 2012, with virtually all public sector infrastructure curtailed or suspended. By 2014 economic recovery was evident but with clear deficits in infrastructure, housing and other sectors which suffered in the property market collapse. From an urban policy perspective, the growth of the economy, the economic crisis and the recovery have provided the backdrop for the development of a more coherent spatial planning perspective which provides the spatial context for the Irish urban system.

In the following subsections the nature of the Irish planning and governance system is described to illustrate the institutional context for the development of urban-related policies. The key actors responsible for urban policy are then described before the evolution of several key urban-related policy areas are traced. Throughout the chapter two key issues guide the exploration of urban policy. Firstly, the role of the planning process is highlighted as it provides a means of framing a wider range of specific policies which impinge on urban areas, notably urban regeneration, housing, transportation and environmental policies. The constant change to the planning system from 2000 to 2019 towards market logic is a primary thread followed. Secondly, the ongoing centralisation of the Irish system is continually noted both in the shaping of past policy and in the framing of current urban policy.

\section{THE INSTITUTIONAL CONTEXT FOR URBAN POLICY: ADMINISTRATIVE AND PLANNING STRUCTURES}

Ireland has traditionally been characterised by a relatively centralised system of government with a narrowly defined devolution of functions to regional and local authorities. The weaknesses of Irish local government have been well documented over the years (Barrington Report 1991; Collins and Quinlivan 2010; Loughlin 2011). From the early 1990s the terrain of local government has been altered through a series of reform processes. Despite these reforms the system remains centralised, with local government spending only 7.6 per cent of total public expenditure (OECD 2018), and it is characterised by large local authority units, the average municipal size (the city or county council) being 151078 (OECD 2018). There are now 31 local authorities in Ireland, which are subdivided into municipal districts. Each of these 31 local authorities since 1963 has acted as a planning authority.

From an urban perspective the local government reforms outlined in Putting People First: Action Programme for Effective Local Government (Government of Ireland 2012) and legislated for in the Local Government Reform Act 2014 have actually been somewhat regressive as town councils were abolished and merged into larger rural/urban municipal districts, which 
play a secondary role to the city and county councils. In two of Ireland's second-tier cities, Waterford and Limerick, their city and county councils were amalgamated, which, it is argued, diluted the urban focus of local government (Moore-Cherry and Tomaney 2019). The reforms of local government, while allocating certain new roles to local authorities in the area of community and economic development and providing some new direct funding streams to local authorities, have made little or no impact on strengthening the role for city or metropolitan governance. The reforms have been criticised as largely bringing about structural rather than democratic changes, as they have failed to accord significant power to the local level and have not resulted in any substantial increase in democratic participation (Quinlivan 2017; Lennon 2019). Indeed, at the same time as new community participation structures are being put in place more generally, opportunities for participation in the planning and development system are being curtailed (Lennon 2019).

Table 4.1 outlines the different levels in the Irish planning hierarchy and the key instruments which influence Irish urban policy, while the sections that follow outline the roles of the most important urban policy actors.

\subsection{National Governance}

At national level there are now four key organisations which have a role in the creation and implementation of urban policy: the Minister for Planning, Housing and Local Government, An Bord Pleanála (The Planning Appeals Board), the Planning Regulator and the Land Development Agency (dealt with in section 4).

At national level the Minister is responsible for the introduction of planning legislation and regulation and for issuing planning guidelines and policy directives to planning authorities and to An Bord Pleanála. The key urban policies at this level are national overarching spatial frameworks: the former National Spatial Strategy (NSS) 2002-2020 and the current NPF. The NPF, in particular, defines the important role for Ireland's urban areas and is backed by funding in the NDP. It was drafted by the Department of Housing, Planning and Local Government and unlike the previous NSS is underpinned by legislation.

Two other national organisations are worthy of mention. Firstly, the newly established Office of the Planning Regulator (OPR), recommended by the Mahon Tribunal (2012), provided for in the National Planning Framework and set up in 2019; it also has a role to play nationally in actively overseeing the planning system. The OPR has taken over the ministerial role of reviewing all local authority development plans and Local Area Plans (LAPs) to ensure that these are consistent with relevant regional or national policies, and recommends ministerial intervention when inconsistencies are recognised. Secondly, An Bord Pleanála, which uniquely gives third parties the right to appeal a deci- 


\section{Table 4.1 Spatial planning organisations and instruments}

\begin{tabular}{|c|c|c|}
\hline Level & Organisation & Planning instruments \\
\hline National & $\begin{array}{l}\text { Minister for Housing, Planning and Local } \\
\text { Government (Department of Housing, } \\
\text { Planning and Local Government) }\end{array}$ & $\begin{array}{l}\text { National Planning Framework: Project } \\
\text { Ireland } 2040 \text { (adopted in 2018) } \\
\text { Ministerial Planning Guidelines (over } 30 \\
\text { sets of guidelines) }\end{array}$ \\
\hline National & $\begin{array}{l}\text { An Bord Pleanála - Independent } \\
\text { Planning Appeals Board } \\
\text { Established initially under the } \\
\text { Local Government (Planning and } \\
\text { Development) Act } 1976\end{array}$ & \\
\hline National & $\begin{array}{l}\text { Office of the Planning Regulator } \\
\text { Established in } 2018\end{array}$ & \\
\hline Regional & $\begin{array}{l}3 \text { Regional Assemblies established on } 1 \\
\text { January } 2015 \\
\text { Replaced the } 8 \text { Regional Authorities and } \\
2 \text { Regional Assemblies }\end{array}$ & $\begin{array}{l}\text { Regional Spatial and Economic } \\
\text { Strategies (RSES) for } 3 \text { Regional } \\
\text { Assemblies: } \\
\text { 1. Eastern and Midlands Regional } \\
\text { Assembly } \\
\text { 2. Southern Regional Assembly } \\
\text { 3. Northern and Western Regional } \\
\text { Assembly } \\
\text { Metropolitan Area Strategic Plans } \\
\text { (MASPs) (for } 5 \text { cities: Dublin, Cork, } \\
\text { Limerick, Galway and Waterford) }\end{array}$ \\
\hline Local & $\begin{array}{l}\text { Planning Authorities ( } 31 \text { City or County } \\
\text { Councils) }\end{array}$ & $\begin{array}{l}\text { City or County Development Plans } \\
\text { Local Area Plans (LAPs) }\end{array}$ \\
\hline
\end{tabular}

sion made by a local planning authority. This national body has more recently been accorded the role of primary decision maker in decisions on strategic infrastructure projects and on strategic housing development, many of which affect urban areas.

\subsection{Regional Governance - Regional Assemblies}

The regional level is composed of three regional assemblies with a coordinating role but weak financial resources and oversight capacities. The main planning input from the regional level of governance is the production of Regional Spatial and Economic Strategies (RSES), which were completed for the Eastern and Midland region in 2019 and the Northern and Western region and the Southern region in 2020, and provide the intermediate layer above the local level in the hierarchy of Irish plans. These strategies combine a spatial 
strategy, an economic strategy, a climate strategy and an investment framework to deliver key infrastructure and services.

Given the emphasis of the NPF on Ireland's cities, there is now a recognition that the major cities incorporate more than a single local authority area. The solution to this is the production of Metropolitan Area Strategic Plans (MASPs) for Ireland's five main cities, which are incorporated into the relevant RSES (Government of Ireland 2018a, p. 134).

\subsection{Local Government - Local Authorities (City and County Councils)}

The day-to-day regulation and management of development in urban areas is carried out by the local planning authorities. The two key planning instruments at local level are, firstly, the statutory local development plans for cities and counties - these being the key planning frameworks at the local level, indicating through zoning the types of development which would be permissible in an area - and, secondly, the more fine-grained Local Area Plans (LAPs) - which operate between the general objectives of the development plan and individual proposals at a local level. The delivery of these plans is largely dependent on the private sector, leading to criticisms of a developer-led approach. The original intention of the Irish planning system was that local authorities would both plan and assist in the development of urban areas. The failure to adequately finance local authorities or to provide them with sufficient powers to generate or initiate development has meant that the planning system has been more regulatory than proactive.

In summary, the Irish system is a three-tier system of national government, regional assemblies and local authorities. It is a highly centralised system with national government exercising control through financing local government, through its role as a legislator and through various powers of direction and guidance. It has a weak regional level and no metropolitan planning; it is the local authorities that have the primary role in overseeing and regulating development in their urban areas and are often key actors in regeneration projects.

\section{EVOLUTION OF RECENT NATIONAL URBAN POLICIES}

The following subsections trace the evolution of national urban policy in Ireland, beginning with the Urban Regeneration Act in 1986 and ending with the outcomes of the financial crash. At a national level, until the 1980s urban policy in Ireland was neglected, and inaction could be linked to inadequate resources and a lack of public finance. Concerted urban policy innovation in relation to urban regeneration began in reaction to the urban dereliction prob- 
lems in the major cities with extensive efforts to achieve property-led urban regeneration from the mid-1980s onwards. The major economic boom of the Celtic Tiger period from the 1990s to 2008 offered opportunities and urban policy alternatives not previously explored. In this period Ireland's main urban centres such as Dublin and Galway experienced major problems with a sprawl pattern of development, increased congestion and a major affordable-housing crisis with demand outstripping supply. Attempts were made to introduce policies to encourage more sustainable, urban forms, including increasing density and the creation of sustainable neighbourhoods. However, the pull of the market versus planning policy and regulations played out during this Celtic Tiger period, leading to a significant property bubble and ultimate catastrophic bust (Kitchin et al. 2010). In the period of recovery, new legislation and policy has been focused on housing delivery and a more concerted attempt to deliver compact urban growth and prioritise the development of Ireland's cities.

\subsection{The 1980s Property-Led Urban Renewal}

In response to severe economic decline, including an unemployment rate of 17 per cent and a dearth of development in cities throughout Ireland, the first comprehensive piece of urban renewal legislation was introduced in Ireland in the mid-1980s in the form of the 1986 Urban Renewal Act. In contrast to the existing planning legislation, this was a pro-development rather than regulatory instrument (Moore 1999). The primary aims of the original Urban Renewal Act 1986 were to stimulate the construction industry and revitalise inner-city areas in Dublin.

In an Irish context this represented a shift from a largely Fordist regulatory environment and form of government and a move towards more entrepreneurial forms. The policy was largely focused on encouraging property-led development through the provision of generous incentives for development in certain designated areas. Tax breaks were chosen as the primary means of incentivising property development and investment in city-centre areas. A variety of fiscal incentives enabled the construction or refurbishment costs of commercial premises or dwellings for owner-occupation or for-profit renting to be offset against income or business tax. These were introduced in 1986 and applied initially to declining districts in the inner areas of Ireland's five cities.

In addition, land assets of public agencies were initially sold at discounted prices, and specialist regeneration agencies such as Temple Bar Properties/ Temple Bar Development and Custom House Docks/Dublin Docklands Development Authority played a major role in facilitating the general regeneration process through innovative flagship developments. These were area-based approaches with an emphasis on physical renewal. The Custom House Docks 
urban regeneration project focused on a previously derelict docklands site was the object of a major integrated development comprising business, residential and recreational functions. The creation of a new International Financial Services Centre was added to this objective, and a special purpose development agency, the Custom House Docks Development Authority, established, with effective planning functions for the area under its administration (Moore 2008). The renewal of Temple Bar (a medieval neighbourhood in Dublin's city centre) to create a newly rejuvenated cultural, artistic and entertainment quarter began in 1990. One of the key changes brought about in this period of regeneration, which is indicative of increasing neoliberalisation, was the bypassing of local authorities using these special purpose regeneration agencies. Both projects had significant physical impacts on the city, and in the case of Temple Bar the regeneration project was the recipient of substantial EU funds (Payne and Stafford 2012).

A major official study of the urban regeneration schemes nationally was carried out in 1996 by government-appointed consultants KPMG (KPMG 1996). At this stage, over IR£1.7 (€2.1) billion of development schemes had been generated, with approximately IR£1 (€1.2) billion of this development occurring in Dublin. This study and other independent research highlighted the success of the schemes in the physical redevelopment of derelict areas, along with the identification of emerging problem areas in policy implementation, which included dead weight (investments that would have occurred anyway), problems with conservation and refurbishment, and the prioritisation of single-use commercial developments over mixed-use development. In addition, the general pattern of development was sometimes viewed as piecemeal, with the absence of urban design/planning criteria leading to poor-quality architecture and urban design. The focus of these tax-based renewal schemes was, as it had been in other countries, an increase in physical infrastructure and development, and the policy was place rather than people based.

\subsection{The 2000s Integrated Urban Regeneration: People- and Place-Based Socially Focused Renewal}

Based on the recommendations of the KPMG report a more strategic and integrated approach to the awarding of incentive designations was introduced in the 1998 Urban Renewal Act. The consultants hoped that a more area-based and integrated approach to renewal would encourage social, economic and environmental rejuvenation (KPMG 1996).

This policy shift in the approach to urban renewal was outlined in the 1998 Urban Renewal Guidelines and a revised programme of urban renewal commenced in 2000. The intention to create a more coherent and holistic approach was reflected in the introduction of a structured programme based 
upon Integrated Area Plans (IAPs) prepared for selected areas. These plans were prepared by local authorities based on criteria established by an expert advisory panel to the Minister of the Environment. The plans were intended to be detailed and area focused, identifying the strengths and weaknesses of the districts involved, targeting those districts with the greatest need or potential for rejuvenation, and selecting sub-areas or key projects for special incentives. Both the creation and implementation of such plans were intended to include consultation with representative groups in the area concerned. Fiscal incentives now formed part of the overall renewal strategy and were intended to be available only where proven barriers to development existed.

The content of IAPs included broad issues such as urban design, sustainable land uses, education, training and local economic development, environmental improvement and traffic management. While land-use powers were vested in local authorities, they had no control over other essential elements such as education and training. A major feature of the IAP scheme was the requirement for a specific monitoring and implementation strategy for each plan and the establishment of a cross-sectoral monitoring committee. This shift in focus was in part influenced by the EU's funding of Urban Regeneration Projects and their stipulation of the need for integrated renewal and for the involvement of communities in this process. The EU-funded Operational Programme for Local Urban and Rural Development 1994-1999 (OPLURD 1994-1999) included a sub-programme for Urban and Village Renewal and a specific stream of funding for Ireland's five cities. This programme stipulated that ERDF-funded renewal was required to have social and economic impacts and multi-sectoral steering groups were established to oversee implementation of the five major initiative renewal projects in the cities; these then provided inspiration for the monitoring committees for the IAPs.

The ambition of the IAPs was that there would be some community gain delivered by the developers from each project. In some instances, this was the inclusion of community infrastructure as part of the development, while in other cases it involved a monetary contribution. A subsequent review of the IAPs revealed that while the scheme had been successfully implemented in development terms, it had been less successful in delivering these social and community benefits and the tax forgone was much greater than the community gain contributions (Brudell and Attuyer 2014; Goodbody Economic Consultants et al. 2006). Given these limitations, critics have argued that the IAPs were largely used as a means of incorporation of working-class protest (Brudell and Attuyer 2014; MacLaran et al. 2007).

Reviews of the impacts of the Urban Renewal Schemes in Ireland commissioned by government (KPMG 1996; Goodbody Economic Consultants et al. 2006) and academic reviews (MacLaran and Murphy 1997; Norris et al. 2014; Williams and Boyle 2012) reveal that while these schemes were initially suc- 
cessful in attracting development into declining neighbourhoods and addressing problems of derelict and underutilised brownfield sites, the extension of their lifespan and spatial focus created negative impacts and deadweight costs for the exchequer.

Despite recognition in the early 2000s that with strong economic growth and almost full employment these financial incentives were becoming increasingly difficult to justify, their lifespan was extended. A strong development lobby, which was benefiting significantly from the incentives, combined with government wariness of dampening economic growth in the construction sector, resulted in the extension of the deadlines for the termination of these schemes on several occasions, initially from 2002 to 2004 then to 2006 (Williams and Boyle 2012). These incentives were finally terminated in 2008. This delayed termination coincided with, and contributed to, a surge in construction activity, as projects were completed to avail of the incentives rather than matching real demand, increasing the market oversupply and contributing to eventual collapse (Kitchin et al. 2010; Williams and Nedovic-Budic 2016).

\subsection{Planning Instruments as Elements of Urban Policy in the Celtic Tiger Boom of the 2000s}

By the late 1990s the negative effects of the Celtic Tiger boom were becoming apparent in Ireland as house prices rose, low-density sprawl continued and speculative house building took place in locations unsuited to large-scale development, notably the outskirts of small rural towns (Williams and Sheils 2000). The need to tackle these issues became part of the urban policy debate and a number of planning guidelines and strategies were published which highlighted the necessity to achieve more compact growth by increasing residential densities. The National Sustainability Strategy published in 1997 - Sustainable Development: A Strategy for Ireland - identified the need to increase residential densities to avoid unsustainable development patterns (Department of the Environment 1997), and planning guidelines published in 1999 - Guidelines for Planning Authorities on Residential Density - provided more detailed national guidance to local authorities in relation to the promotion of higher residential densities in appropriate urban areas (DoELG 1999).

The Planning and Development Act 2000, which consolidated a range of legislation from 1963 to 1999 in one act and modernised the planning system, for the first time provided a more coherent hierarchy of cascading plans national, regional and local (Grist 2012). The Act did not provide a legislative basis for a national plan but provided the underlying legislation for a set of regional planning guidelines which were to provide the means for the delivery of the National Spatial Strategy (NSS) (Government of Ireland 2002) which was published in 2002 . 
The NSS, for the first time, provided a 20-year planning framework for the country with the aim of achieving a better balance of social, economic and physical development between regions. It recognised that the Greater Dublin Area's rapid development had driven much of the country's economic success, but that this had created significant congestion issues. The NSS aimed to support Dublin's continued performance through urban consolidation and a reduction in sprawl. In an effort to achieve balanced regional development, eight 'gateway cities' were identified in the regions; and nine strategically located medium-sized 'hubs' with populations of 20000-40000, which would link to their wider rural hinterlands, were also designated. The actual implementation of the strategy was, however, stymied, as the ability to concentrate development within these designated urban gateways and hubs was limited by a political willingness to allow dispersal, both through other government initiatives (including a major relocation of government jobs to non-designated towns) and through rural housing guidelines which did little to curtail rural housing development (DoEHLG 2005).

It was also evident that local authorities were failing to align their development plan policy with the ambitions of the NSS and density guidelines, as sprawling low-density suburban development remained the norm and commuter towns in the counties surrounding Dublin grew exponentially. Despite all the guidance on the appropriate locations for development and the need for higher residential densities and integrated compact growth, the demands of development meant that the primary driver remained the market, and a pro-growth, pro-development planning system was largely supportive and facilitative of this (Daly 2016).

The pro-development approach was also evident in a number of new fast-tracking elements which were introduced to the Irish Planning System by national government. The 2000 Planning and Development Act provided for the designation of Strategic Development Zones (SDZs), specifically designated areas wherein a fast-track mode of planning would operate to deliver development that is considered of strategic social or economic importance to the state. With reduced opportunities for appeal, the time frame for the grant of permission is reduced and greater certainty is created for developers, as the Act removed one of the democratic elements for participation by members of the public. Since the introduction of the legislative provisions, $12 \mathrm{SDZs}$ have been designated across the country. These are predominantly located in urban areas, and the majority of the SDZ planning schemes make provision for the development of major new housing areas with accompanying transport and education infrastructure, retailing and commercial activity, and amenity areas.

A second strategic fast-track planning mechanism was introduced in 2006 through the provisions of the Strategic Infrastructure Act 2006. This Act removes decision-making powers on certain infrastructure projects entirely 
from Local Authorities, giving them to a strategic infrastructure division of An Bord Pleanála. The legislation lists the classes of development that can potentially constitute strategic infrastructure and includes energy, transport, health and environmental infrastructure. The legislation provides the opportunity for the promoter of a project to consult with An Bord Pleanála, which decides if the development proposed constitutes strategic development. As with the SDZs, the opportunity for the public to engage on these applications is reduced. The provisions of this legislation de facto strips the local authority of a significant role in the decision making on major infrastructure projects, and limits opportunities for public engagement.

During the early 2000 s, much urban policy in the booming economy was focused on facilitating growth, particularly the delivery of housing, and urban regeneration policy was focused on the regeneration of public sector flats (apartment) complexes in inner urban areas. The pro-development stance of national government policy and entrepreneurial local authorities competing with each other for development led to a system which fuelled rather than dampened a speculative housing boom (Kitchin et al. 2012).

\subsection{Economic Crisis an Impetus for Change}

As the global economic crisis began in 2008, the Irish banking sector experienced the effects - deposits contracted, mortgage lending collapsed, bad loans increased, and it became evident that the value of the property assets on which capital had been borrowed was grossly overestimated - and banks faced increasing difficulties in borrowing on international markets. The property speculation bubble, financed via reckless lending by Irish banks underpinned by the international bond markets, burst.

As the Irish banking system was on the verge of collapse in September 2008, the government guaranteed the deposits and liabilities of all major Irish-headquartered banks. This interlinking of sovereign and banking debt undermined the creditworthiness of the Irish state. By 2010, the government found itself unable to borrow, and because of this fiscal and sovereign debt crisis was forced to seek a bailout from the EU, European Central Bank (ECB) and the International Monetary Fund (IMF). The subsequent period of austerity as the state struggled to rebalance its finances had significant effects on urban development. Major capital projects were put on hold, regeneration projects in social housing estates stalled, unfinished housing and commercial development dotted the landscape (Kitchin et al. 2010), deep cuts were made to community and voluntary association funding (Harvey 2012) and efforts to reduce public finances led to the local government reforms outlined above. The fallout and implications of this period have led to changes to the Irish planning and development system, with implications for urban policy. 


\section{ACTORS: WHO IS DRIVING THE CHANGES?}

\subsection{National Government}

The Irish government, through its Minister and junior ministers in the Department of Housing, Planning and Local Government, exerts significant influence on the country's cities and towns and fundamentally shapes the policy framework. Historically, the dependence on central government finance has limited local authorities' ability to be proactive in initiating development projects in urban areas.

In addition to overseeing policy making in the areas of planning, housing and local government, the Minister has the capacity to direct local authorities to take on board the policies contained in nationally (NPF) and regionally (RSES) produced plans, thus ensuring that local authorities do not deviate from these plans. The Minister is also responsible for issuing ministerial planning guidelines and directions, which can supersede locally made policy. The ministerial influence through planning guidelines was further strengthened in 2015 when legislation was amended to allow the relevant Minister to include 'specific planning policy requirements' in guidance. These are specific requirements which local authorities must adhere to.

The issue of central policy guidelines and the tension between the policy direction contained therein with the policy outlined in the local development plans drafted by the local authorities and approved by the local councillors has proved controversial. Recent changes have been criticised as they are viewed as undermining the role of locally elected members. The publication of Guidelines for Planning Authorities on Sustainable Urban Housing: Design Standards for New Apartments (DHPLG 2018a), which specifically disallows local authorities from including design standards for apartments (for example floorspace, amount of open space, requirements for dual aspect) that go over and above the requirements in national guidance, are a case in point. This is indicative of further centralisation of the Irish system, as the guidance put in place in democratically adopted development plans are overridden by national guidance. Increasing flexibility and a focus on efficiency have become the dominant thrust of national urban planning policy.

\subsection{Regional Actors}

The major lacunae in the governance of Irish urban areas is the lack of regional and in particular metropolitan governance for Ireland's city regions. There are no strong structures for regional governance and there is little allegiance to the region as a concept (Breathnach 2014). The members of the three regional 
assemblies (the Northern and Western Regional Assembly, Southern Regional Assembly and Eastern and Midland Regional Assembly) are not directly elected, but elected members are nominated by the constituent local authorities to serve on the Regional Assembly, and it is to the local authority that their main commitment lies.

This reluctance to engage with the governance of metropolitan areas is exemplified in the debate on whether or not directly elected mayors should become part of the Irish local governance hierarchy. While the citizens of Cork, Limerick and Waterford voted in May 2019 in three plebiscites on whether to put in place a directly elected mayor, only the citizens in Limerick voted in favour. Dublin was not included in these plebiscites, as it was deemed that the complexities surrounding local government in the Dublin metropolitan area were too great and required a longer period of discussion. The government subsequently approved the setting up of a Citizens' Assembly to consider the best model of local government for Dublin and, in particular, the issue of a directly elected mayor and his or her powers. To date this Citizens' Assembly has not been recruited or convened.

While the governance structures underpinning the regions might be criticised, the Regional Assemblies have a number of important roles in relation to territorial spatial planning. The new Regional Spatial and Economic Strategies (RSES) provide the intervening link between the NPF and county and city development plans and specify the detailed tailored approach to development and where it will occur in the region. The RSES will be implemented through the constituent City and County Development Plans, Local Area Plans (LAPs) and Local Economic and Community Plans (LECPs), which are required to be consistent with the RSES. Other state agencies and government departments are also statutorily required to adapt their sectoral plans to align with and support the delivery of the RSES.

This is a significant change in terms of regional planning in an Irish context. The former NSS and the regional planning guidelines lacked statutory backing and initially there was no requirement for local development plans (for the cities and counties) to adhere to the guidelines. In 2010, legislation was passed to ensure that through their core strategies local development plans would be consistent with regional and national guidance. Subsequently, the Local Government Reform Act 2014 provided the legislative context for government departments and other state agencies to support the implementation of the RSES. The regional assemblies therefore have an important oversight role in ensuring the plans from their constituent local authorities are coherent with the RSES and the NPF. The current hierarchy of plans and instrument provides the wider context for delivering the targets specified in the NPF, which is discussed further below. 
A further innovation and reflection of the importance of metropolitan areas in Ireland's spatial and economic development are the Metropolitan Area Strategic Plans (MASPs), which have been incorporated into each of the RSESs and provide a long-term, 12-year strategic and investment framework for Ireland's five city metropolitan areas. While the production of MASPs is a formal recognition of the existence of metropolitan areas and their functional areas, the main gap that still remains, as pointed out above, is that there are no institutional metropolitan governance structures which could effectively give weight to the MASPs and ensure their implementation (Moore-Cherry and Tomaney 2019).

The Regional Assemblies also play a role in the management and implementation of the two Irish Regional EU Operational Programmes (the Border, Midland and Western Regional Operational Programme 2014-2020 and the Southern and Eastern Regional Operational Programme 2014-2020) which distribute the co-funding from the ERDF to the various regional applicants. The spatial coverage of the operational programmes is indicative of the lack of coherence in governance arrangements at regional level as they cut across the current boundaries of the three regional assemblies.

\subsection{Local Authorities}

The responsibility for planning and development in urban areas lies with the local level of government and the city and county councils. The intention of the 1963 Local Government Planning and Development Act was that the local planning authorities would have a dual role: that of an agency, to stimulate and instigate development, and that of a regulator, to control development by the adoption of a development plan with statutory force. The ability of local authorities to involve themselves to any great extent in development activities, including site assembly and delivering development projects as envisaged under the 1963 Act, was severely restricted by their lack of independent finance. Thus, historically, local authorities have struggled to deliver major regeneration projects in cities and towns and the physical planning system has evolved with a disproportionate emphasis on development control and little involvement in implementation and strategic urban policies or planning. This has led to local authorities being bypassed by the setting up of independent quangos such as the Dublin Docklands Development Corporation or Temple Bar Properties, and more recently the Land Development Agency.

The constraints on local authorities raising local finance have also exacerbated the pro-development ethos of local authorities. In the absence of strong local taxation, and a reliance on business rates, local authorities have relied on the revenue from planning levies (charges to developers for various services on the grant of permission) and on income from planning fees to augment their 
finances, thus fuelling pro-growth entrepreneurial policies. Furthermore, local authorities anxious to facilitate commercial development and its attendant rates often end up in competition with neighbouring local authorities, which can inhibit collaboration in metropolitan areas.

Utilising the provisions created through national policy initiatives, local authorities have been lead partners in various partnerships for areas of their cities, either as project leads in regeneration projects framed by Integrated Area Plans (IAPs) and in EU co-financed regeneration projects, or as the lead planning agencies in SDZs. The difficulty is that often a single project will require multiple sources of funding and the use of a range of different instruments and initiatives to deliver a meaningful integrated outcome. However, the erosion of local authority power in relation to various decision-making processes and the creation of new national agencies documented in this chapter undermines the role of local authorities and the overarching framework of the local development plan.

\subsection{EU Influence}

The impact of the EU on Ireland's cities and towns is manifold. Bannon argued that there were four ways in which this EU impact has been manifested: through EU environmental directives which have protected and enhanced elements of the environment; through various urban-related funding programmes and initiatives, notably Urban Pilot Projects (UPPs), and Urban I and II; through structural and cohesion funding for urban projects; and through networking and exchange programmes (Bannon 2007, p. 239). Currently, many Irish local authorities are members of URBACT networks and are involved with other European cities and towns in sharing innovative practices. To these four drivers could be added the significant influence that the language and discourse of the various declarations and charters have had on Irish urban guidelines, particularly in relation to the sustainability agenda, and the influence of the European Spatial Development Perspective (ESDP) on Irish spatial planning.

In their exploration of the influence of EU initiatives and European urban policies on policy evolution in Ireland, Williams and Varghese (2018) found that EU Cohesion Policy, EU directives and the ESDP had strongly influenced Irish spatial planning and territorial governance during the period 2000-2016. The influence of EU policy can be seen in the shift in Irish planning towards a more strategic and regional approach from the previous local development led approach. In addition, the financial planning that is central to EU support has made the initiation and implementation of major strategic infrastructure investments more realistic. 
The availability of EU structural funds, particularly ERDF funds, has played an important role in facilitating renewal projects. This was particularly so during the 1990s and early 2000s, as alluded to in the section on the evolution of national urban policy. More recently, under the 2007-2013 and 2014-2020 Partnership Agreements between the EU and Irish government an urban renewal funding scheme was put in place for the NSS-designated Gateways and Hubs. A pilot Gateways and Hubs Grants Scheme was introduced under the 2007-2013 Regional Operational Programmes (€28 million ERDF funding), and this was replicated in the 2014-2020 Operational Programmes through the Designated Urban Centre Grant Scheme. Under this scheme, regeneration projects which were part of integrated strategies to tackle the social, economic, environmental, climate and demographic challenges affecting the areas concerned were funded, with $€ 40$ million of ERDF funds contributing to an overall budget of $€ 127$ million (co-financed by local authorities). This funding was particularly important during the period of austerity from 2008 to 2013 when the government's Gateway Innovation Fund, which was intended to fund flagship infrastructure in the NSS gateways, was deferred and EU funds allowed some capital investment projects to continue, albeit in a scaled-back manner.

\subsection{Do Parties Matter?}

Since 1981 every Irish government formed has been a coalition between either one of the two major parties Fine Gael or Fianna Fail and one or two other parties from across the political spectrum. Coalitions require compromise and this has augured well for the development of urban policy when smaller parties or independent politicians in coalition place an emphasis on social or environmental priorities with an urban emphasis. The two main political parties are both moderate conservative, centre-right parties and do not differ to any great extent ideologically.

Both the main government parties are supportive of market logic and have been champions of the development industry. This has meant that to a large extent market-supportive policy in urban areas, in the form of tax incentives and a focus on private housing development, has been the predominant policy thrust over the past 40 years. The long period of these parties' being in power has meant that entrepreneurial, market-based projects have been the norm, with very little challenge to these. In general, urban policy has not been a key focus of Irish political debate; however, housing and climate issues were significant issues in the February 2020 general election.

In the Irish context, the national government is the significant player in framing urban policy. As the evolution of urban policy has shown, all the key urban policies emanate from this level of government and most funding is centrally allocated to local authorities. Local government policy is shaped 
by policy direction from above and the tendency has been towards the establishment of new centralised government agencies. While centralisation can contribute to coherence in relation to national spatial planning, there is the danger of a democratic deficit emerging.

\section{SPECIFIC POLICIES}

This section focuses on the most recent and influential Irish urban policies and implementation mechanisms; it confines itself to planning, regeneration and housing as the main elements of urban policy.

\subsection{Planning Policy: The National Planning Framework 2018-2040}

As outlined in the introduction, the National Planning Framework (NPF) published in 2018 provides the most important overview of Irish urban policy as well as the context for strengthening Ireland's urban hierarchy. In terms of urban policy, the 11 National Policy Objectives contained in the NPF provide a set of overarching policy objectives for Ireland's urban areas.

The thrust of these policy objectives is to ensure urban areas are attractive, liveable and well-designed, offering communities a high quality of life and well-being while creating cities and towns which are internationally competitive and drive national and regional growth. The regeneration of existing settlements in a more compact manner is recognised as being fundamental to sustainability and better environmental outcomes. In terms of territorial development, National Policy Objective 7 provides an indication of the desired development of Ireland's urban structure. The ambition is for significant population growth in Ireland's five cities (Dublin, Cork, Limerick, Galway and Waterford) and within the built-up areas of these and other towns and villages, to avoid some of the characteristic sprawl of many settlements. The failed legacy of previous approaches, which has resulted in commuter towns without adequate facilities and amenities and towns which lack the requisite employment and services functions, is being addressed through the identification of opportunities for strategic employment development, enterprise location and relocation.

In line with the overarching emphasis on creating more compact urban areas, a central policy objective is to develop within existing settlements and to make more efficient use of infill and brownfield development sites. The objective is for 40 per cent of all new homes to be constructed within the built-up footprint of existing settlements countrywide. In the five cities and their suburbs the goal is for at least 50 per cent of all new homes to be within their existing built-up footprints; in other settlements the target is 30 per cent. 
This compact growth is to be facilitated by investing in sustainable transport systems and supporting amenities and financing significant regeneration projects. Unlike the case of the former NSS (which was not specifically linked to National Development Plans), the objectives in the NPF are now tied to strategic investment outlined in the National Development Plan 2018-2027 (NDP). A new funding instrument, the Urban Regeneration and Development Fund (URDF), and a new Land Development Agency (LDA), together with a tranche of major infrastructural projects (including sustainable transportation infrastructure such as the BusConnects projects for Ireland's cities, an expansion of Dublin's commuter rail system the DART and the construction of a Metro Link in the capital), are all provided for in the NDP. There is a real recognition that the ambitions of the NPF need to be underpinned by such investment, and this moves the NPF beyond an aspirational vision (Lennon et al. 2018).

\subsection{Urban Regeneration Funding}

The Urban Regeneration and Development Fund (URDF) is an important component of national urban policy that was launched in July 2018 (DHPLG 2018 b). The URDF is to provide $€ 2$ billion in funding up to 2027 to renewal and redevelopment projects in cities and large urban centres (all towns with a population of over 10000 are eligible to apply). The first call for bids was made in 2018 with $€ 100$ million allocated to projects beginning in 2019 , an overall amount of $€ 550$ million being allocated to the fund up to the end of 2022.

The fund requires that public sector agencies (ideally local authorities), acting as lead partners, make competitive bids for the fund, with the aim of initiating projects which rejuvenate underutilised areas for commercial, housing and public realm improvements. The projects themselves are required to be catalytic and likely to leverage other funding, public and private, and are to address the objectives of the NPF in ensuring that significant future development occurs within the built-up areas of the cities and towns. The applicants are required to provide 25 per cent co-funding (from public and private sources) and to demonstrate that the proposal would leverage an additional 100 per cent private funding. The proposals deemed eligible for funding are broad-ranging, from those relating to active land management to facilitate future development to those which are actively delivering public realm improvements, new transport infrastructure or community infrastructure as well as projects focused on transitioning to a low-carbon economy.

The first call for bids was made in July 2018, and 189 applications were received from which 88 projects were approved. A number of the funded projects are contributing to major coordinated proposals for city centre renewal, 
for example the Living Georgian City Project in Limerick, which draws on a number of funding sources to regenerate the Georgian core of Limerick city.

This URDF is the first concerted state-led investment in urban regeneration since the capital investment in major initiative regeneration projects (co-financed by the ERDF) in the 1990s. This scheme is complemented by two smaller regeneration initiatives. Firstly, there is the Living City Initiative, which is a tax incentive scheme operational from 2015 until 2022 for special regeneration areas in the five Irish cities: Dublin, Cork, Limerick, Galway, Waterford and in the historic town of Kilkenny. This allows owner-occupiers and landlords to claim tax incentives for the refurbishment and conversion of pre-1915 buildings for commercial or residential use. Secondly, six small pilot towns of circa 2500 population were allocated funding of up to $€ 100000$ to explore and develop innovative proposals to encourage the reuse of vacant and underused buildings in town centres under the Town Centre Living Initiative.

These schemes could prove to be a catalyst for the regeneration of many areas of Ireland's cities and towns, but they are dependent on the local authorities committing to the prioritisation of compact development in their town centres and, crucially, on the public choosing to live there. This is a particular challenge beyond the major cities and towns where single-family homes on large plots in the countryside remain a key component of new housing development and are still facilitated in the NPF (Lennon et al. 2018).

\subsection{The Land Development Agency}

A key initiative announced as part of the NPF and NDP was the setting up of a new semi-state agency called the Land Development Agency (LDA). In what is a new departure in Irish planning and urban development, the LDA launched in 2018 will be involved in active land management in an effort to unlock the potential of public lands for housing development and to stimulate regeneration. Its two main functions are to coordinate the regeneration and development of appropriate state lands to effectively deliver housing and to drive strategic land assembly in conjunction with public and private sector landowners.

In line with the provisions of the Rebuilding Ireland Strategy (see below), an important remit of the LDA is to provide affordable housing. On all public land within its remit the agency must deliver at least 40 per cent of the housing in the form of social and affordable housing (10 per cent social, 30 per cent affordable). The LDA is committed to providing this on public land and is pioneering a model of cost rental housing on land under its control. ${ }^{1}$ Overall the LDA is tasked with delivering 150000 new homes by 2040, which is a significant challenge. In order to carry out its functions, funding of $€ 1.25$ billion has been earmarked by government to finance it. 
The LDA's initial portfolio consists of nine major urban brownfield sites in public ownership and includes former hospital sites, army barracks, railway yards and other former industrial lands, all located in city-centre or suburban areas. In line with its role as a national centre of expertise, the LDA has in-house experts in the areas of financing and development and is working in partnership with public agencies in putting together integrated masterplans (where they do not already exist) for the development of these sites. The LDA will have a role in assembling the land and in coordinating the delivery of infrastructure to these sites. Given the scale of the development proposed and the strategic nature of the sites, there is a considerable opportunity for ensuring high-class design and for integrating these sites with existing local communities.

The early signs are that the LDA is working closely with local authorities in advancing plans for the major sites and key urban development projects are benefiting from high-level design reviews. There is evidence that the physical outcomes will be good. What is less apparent are the potential social and economic outcomes from this significant investment. It will be vitally important that these are delivered, and that considerable effort is expended in engaging with the wider public in the development of these key strategic sites.

\subsection{Housing Policy as a Component of Urban Policy}

Since the establishment of the Irish state the dominant approach to housing in Ireland has been the promotion of owner occupation. This has been supported through financial incentives such as mortgage interest relief, incentives for first-time buyers, direct subsidies for purchasers, right-to-buy schemes for social housing tenants, shared-ownership schemes and government-backed home loans (Redmond and Norris 2014; Norris 2016). Social housing has predominantly been provided by local authorities and, to a lesser extent, non-profit housing associations ( 8 per cent of all housing is rented from local authorities and less than 1 per cent from housing associations) (CSO 2017). In contrast to many European countries, social housing has become increasingly residualised, targeted at the poorest households (Redmond and Norris 2014). The main policy thrust in current Irish housing policy is to rely on the private sector to deliver social and affordable housing through various mechanisms.

One of the means of leveraging social and affordable housing provision is through Part V of the Planning and Development Act 2000. This component of planning legislation legally obliges private sector developers to subsidise social and affordable housing on residential development sites (DoELG 2000). Developers were initially required, as a condition of planning permission in housing and apartment developments of more than four units, to transfer to the local authority up to 20 per cent of the site for use as social and/or affordable 
housing. A significant element of the legislation is that the site must be transferred to the local authority at existing-use value rather than current market value. There are a number of options available to developers to deliver the requirements, although the preference of local authorities is to have housing units transferred. The legislation had two aims. Firstly, it aimed to allow local authorities to access development in a cost-efficient manner, thereby enabling them to subsidise the provision of social and affordable housing. The second, more social aim, or social engineering aim, was to reduce what was seen as the undue segregation between public and private housing by creating mixed tenure developments to encourage social mix and social interaction (Russell and Redmond 2009). In 2015 an amendment to the legislation reduced the requirement for transfer to 10 per cent of developments of over nine units.

During the boom years of the Celtic Tiger there was an increasing reliance on the private sector, both to deliver social housing using Part V of the Planning and Development Act 2000 and to regenerate large existing social housing estates, which were in poor condition and required renewal. The renewal approach taken from 2001 was to leverage the increase in land values of these estates that was precipitated by the property boom and to regenerate them using the mechanism of Public Private Partnership (PPP).

This form of regeneration using PPP involves the transfer of public land to a private developer who can build and sell owner-occupied housing and commercial retail units in return for providing a reduced amount of new social housing and accompanying community facilities. The aim was to demolish the existing social housing flat complexes and ensure their redevelopment at a much higher density as mixed tenure estates. As with the Part V provisions, the argument is that mixed tenure would create a better social mix and reduce concentrations of social housing which were often viewed as failed entities. To a large extent this was a state-sanctioned gentrification process (Kelly 2014).

Ostensibly, this approach was to be a no-cost solution for the state (although this is disputed, Hearne 2011). In Dublin City Council's area, by 2008, at the time of the property crash, 12 local authority estates had been earmarked for this form of renewal, with other schemes proposed in Limerick and a number of other regional towns. The onset of the economic crisis meant that the entire premise on which these PPPs were based was undermined. The developers who had initially engaged with the process withdrew, leaving the communities in these estates with little prospect of upgrading their dwellings and the estates subject to further deterioration due to de-tenanting and lack of investment (Hearne and Redmond 2014).

\subsubsection{The economic crisis and housing policy}

One of the outcomes of the property market crash and subsequent years of austerity was a severe contraction in development activity across the country, 
including in urban areas. With significant constraints on capital spending there was little or no opportunity for public sector investment in major renewal projects and in particular for investing directly in social housing provision.

The market collapse associated with property meant that for a period from 2010 to 2016 , during the recession and early years of recovery, housing development contracted significantly. At the lowest point in 2013 only 8301 units of housing were completed nationally in Ireland. The crisis in public finances which resulted in drastic cuts to capital spending on the direct provision of social housing, coupled with a dependence on the private sector through Part $\mathrm{V}$ and PPPs for the provision of social and affordable housing, meant that there was also a very limited amount of social housing constructed during this period - a mere 293 units in 2013 (DECLG 2014). With minimal housing construction over the period, as the economy recovered and the population continued to grow, shortages of housing became apparent. With few new homes being built, demand in the private rented sector grew, pushing up rents.

The lack of provision of social housing in particular caused difficulties for those who were either dependent on social welfare or who were on low incomes. The people in this group were priced out of the rental market by rising rents, and the scarcity of alternatives led to rising levels of homelessness. As the state had been relying on subsidising the private sector to provide housing to those in need, through leasing agreements and rent supplements, this also put pressure on rents. As the Irish economy recovered, the policy context was dominated by the pressure to address the crisis in the housing system. While the failure of previous market-based and neoliberal policy might have provided pause for thought in relation to the production of entrepreneurial urban policy, in essence what has evolved is a deepening of neoliberalisation in planning and urban policy instruments.

\subsubsection{Post-crisis policy - rebuilding Ireland, deepening neoliberalisation}

In order to tackle the growing housing crisis, the government produced a new housing policy document entitled Rebuilding Ireland: Action Plan for Housing and Homelessness (Government of Ireland 2016). This action plan aims to increase housing supply through measures in five action pillars: (1) address homelessness, (2) accelerate social housing provision, (3) build more homes, (4) improve the rental sector, and (5) utilise existing housing. The overall aim is to facilitate the provision of some 100000 new housing units in the period 2017-2020 and to deliver 50000 social housing units in the period to 2021.

To increase the supply of housing, a number of initiatives have been launched to increase output; these include the setting up of the Land Development Agency and the utilisation of state lands (see above); the establishment of a Local Infrastructure Housing Activation Fund, a €200 million 
fund to provide enabling infrastructure to open up key sites for housing development; and planning reforms. The latter included the introduction of a fast-track system for large-scale housing developments - Strategic Housing Development - and the publication of new guidance on build-to-rent apartment accommodation and shared accommodation (student housing and co-living). The Guidelines for Planning Authorities on Sustainable Urban Housing: Design Standards for Apartments (DHPLG 2018a), which have been heavily influenced by the development industry (Lennon and Waldron 2019), have specifically reduced the standards required in build-to-rent and shared accommodation schemes in terms of private open space, car parking and provision of childcare, and have increased the number of studio and one-bedroom units that are permissible within apartment schemes. These are at odds with previous standards in the development plans of many urban authorities. Coupled with national guidelines on building heights set out in Urban Development and Building Heights: Guidelines for Planning Authorities (DHPLG 2018c), which explicitly prohibit urban local authorities putting in place blanket height guidelines, this means that local authorities have much less leeway to influence the design of apartment developments in their functional areas.

\subsubsection{Strategic housing development}

A key change introduced in response to Rebuilding Ireland is the introduction of fast-track Strategic Housing Developments. This legislative provision introduced in 2016 allows large housing applications of a hundred units or more and applications for student accommodation of $200+$ bed spaces to be made directly to An Bord Pleanála, bypassing the local authority decision-making system. While this was initially introduced for a two-year period, it has been extended until the end of 2021.

The aim is to incentivise large-scale housing production through reducing the time required in the planning system, as there is no third-party appeals process. An Bord Pleanála becomes the decision-making authority in the first instance - albeit with a role for consultation with the local authority and an opportunity for submissions by members of the public. As An Bord Pleanála can contravene the local development plan in the strategic national interest, the process circumvents the local democratic system and usurps the role of locally elected representatives who are responsible for adopting the local development plan. This is another incidence of a move away from local authorities to the centre and much more firmly establishes An Bord Pleanála as a national decision-making body and less as a forum for challenge and appeal.

Housing is currently the key challenge of urban policy and a priority of government. As a result, some progress is being made on the delivery of housing, including the delivery of a greater number of social housing units. Significant challenges do remain however, not least in relation to the thorny 
issue of affordability, although some inroads may be made in this regard through the LDA. The emphasis on securing social housing through the private rented sector, either through direct payment of rent by local authorities to private landlords by way of Housing Assistance Payments (HAPs) and Rent Supplement (RS) (via the Rental Accommodation Scheme), or through long-term leasing arrangements, is also problematic. Rising rental costs leave a limited choice for HAPs and RS recipients, and for local authorities the costs associated with these schemes are rising. The construction of social housing guards against this and also provides counter-cyclicality in housing output. However, although there has been an increase in social housing construction, it is only addressing a small portion of the current need (Byrne and Norris 2018; Watson and Corrigan 2019).

\section{CONCLUSIONS}

The current focus on urban areas in spatial policy illustrates that Irish urban policy has moved centre stage, following many years on the margins. Although there is no explicit urban policy, national-level spatial planning is now focused on delivering balanced regional development and compact city growth. There is recognition in the National Planning Framework of the vital role of towns and cities in Irish spatial and economic development and that the spatial and economic are intertwined. It is promising that the NPF is promoting a more compact urban form and has moved the debate on urban and regional development to national objectives in place of a purely local growth issue. This represents a significant change in ambition from the historically highly localised form of planning that has existed in Ireland and the extent to which local pro-development politics have favoured decentralised growth. For the first time cities are at the foreground of national policy and a national spatial plan is closely aligned with the funding mechanism of the NDP. It is also encouraging that a well-funded regeneration programme to support the ambitions and requirements of the urban centres earmarked for consolidation is in place and that more active land management through the LDA will conceivably deliver a greater quantum of social and affordable housing.

There are a number of downsides to this approach to urban policy. The first is that economic development is the overarching priority, and this tends to supersede other elements of policy areas. It can also be argued that the NPF and NDP reinforce the role of planning activities as direct physical development enablement and facilitation rather than balancing the conflicting interests of society and prioritising issues of equity, social justice and environment (Lennon et al. 2019).

A second critical trend is the growing centralisation of power at national level. This is evident in the enhanced Ministerial role of the Minister for 
Housing, Planning and Local Government, the new powers of decision making granted to An Bord Pleanála in Strategic Housing Development, and the establishment of the Land Development Agency and the Office of the Planning Regulator. The centralisation of power further emasculates the local authority and creates distance between the directly elected representatives and the shaping and delivery of policy and projects. This runs counter to the principles of the Urban Agenda of the European Union (established in 2016) which promotes subsidiarity and suggests that urban authorities, as the level of government closest to citizens, should have the key role in the governance of urban areas.

Centralisation of power through its removal from the local level and through reducing opportunities for public participation in various elements of planning is consistent with the ongoing neoliberalisation of the Irish planning system. This is a continuing tendency in the Irish context whereby planning legislation has been shaped to support and facilitate an entrepreneurial approach to governance and to support development capital (Fox Rogers et al. 2011). Given the legacy of an Irish planning system that from the outset was development led, and urban regeneration policy and housing policy which historically relied on the private sector as the delivery mechanism, as noted in this chapter, this is not surprising. The NPF and NDP offer new opportunities for urban Ireland and the MASPs provide a framework for metropolitan collaboration among local authorities. Only the future will tell if these can deliver the more sustainable urban places which they envisage.

\section{NOTE}

1. This is a new departure in an Irish context, where in contrast to other European countries cost rental housing has not been used heretofore.

\section{REFERENCES}

Bannon, M. J. (2007), 'Ireland: metropolitan dominance the challenge in achieving balanced territorial development', in L. van den Berg, E. Braun and J. van der Meer (eds), National Policy Responses to Urban Challenges in Europe, Aldershot: Ashgate, pp. 217-244.

Bannon, M. J. and M. Grier (1998), 'Ireland', in L. van den Berg, E. Braun and J. van der Meer (eds), National Urban Policies in the European Union Responses to Urban Issues in the Fifteen Member States, Aldershot: Ashgate, pp. 181-223.

Barrington Report (1991), Local Government Reorganisation and Reform: Report of the Advisory Expert Committee, Dublin: Stationery Office.

Breathnach, P. (2014), 'Creating city-region governance structures in a dysfunctional polity: the case of Ireland's National Spatial Strategy', Urban Studies, 51 (11), 2267-2284. 
Brudell, P. and K. Attuyer (2014), 'Neoliberal "regeneration" and the myth of community participation', in A. MacLaran and S. Kelly (eds), Neoliberal Urban Policy and the Transformation of the City: Reshaping Dublin, Basingstoke: Palgrave Macmillan, pp. 203-218.

Byrne, M. and M. Norris (2018), 'Procyclical social housing and the crisis of Irish housing policy: marketization, social housing, and the property boom and bust', Housing Policy Debate, 28 (1), 50-63. DOI: 10.1080/10511482.2016.1257999.

Collins, N. and A. Quinlivan (2010), 'Multi-level governance', in J. Coakley and M. Gallagher (eds), Politics in the Republic of Ireland (5th ed.), London: Routledge, pp. 384-403.

CSO (Central Statistics Office) (2017), Census 2016 Summary Results Part 1, Cork: Central Statistics Office.

Daly, G. (2016), 'The neo-liberalization of strategic spatial planning and the overproduction of development in Celtic Tiger Ireland', European Planning Studies, 24 (9), 1643-1661, DOI: 10.1080/09654313.2016.1190813.

DECLG (Department of the Environment, Community and Local Government) (2014), Housing Statistics Bulletin 2014, Dublin.

Department of the Environment (1997), Sustainable Development: A Strategy for Ireland, Dublin: Stationery Office.

DHPLG (Department of Housing, Planning and Local Government) (2018a), Sustainable Urban Housing: Design Standards for New Apartments, Dublin: Department of Housing, Planning and Local Government.

DHPLG (Department of Housing, Planning and Local Government) (2018b), Circular FPS 05-2018 - Urban Regeneration and Development Fund - Call for Proposals, accessed 15 July 2020 at https://www.housing.gov.ie/search/archived/current?query $=\% 22$ urban $\% 20$ regeneration $\% 20$ and $\% 20$ development $\% 20$ fund $\% 22$.

DHPLG (Department of Housing, Planning and Local Government) (2018c), Urban Development and Building Heights: Guidelines for Planning Authorities, Dublin: Department of Housing, Planning and Local Government.

DoEHLG (Department of the Environment, Heritage and Local Government) (2005), Sustainable Rural Housing: Guidelines for Planning Authorities, Dublin: Stationery Office.

DoELG (Department of the Environment and Local Government) (1999), Guidelines for Planning Authorities on Residential Density, Dublin: Department of the Environment and Local Government.

DoELG (Department of the Environment and Local Government) (2000), Implementation Manual Part V of Planning and Development Act, 2000, Dublin: Department of the Environment and Local Government.

Fox Rogers, L., E. Murphy and B. Grist (2011), 'Legislative change in Ireland: a Marxist political economy critique of planning law', Town Planning Review, 82 (6), 639-668, DOI: 10.3828/tpr.2011.37.

Goodbody Economic Consultants in association with Mazars and HKR (2006), Review of Area-Based Tax Incentive Renewal Schemes, Dublin: Department of Finance.

Government of Ireland (2002), National Spatial Strategy for Ireland 2002-2020: People, Places and Potential, Dublin: Stationery Office.

Government of Ireland (2012), Putting People First: Action Programme for Effective Local Government, Dublin: Stationery Office.

Government of Ireland (2016), Rebuilding Ireland: Action Plan for Housing and Homelessness, Dublin: Stationery Office. 
Government of Ireland (2018a), Project Ireland 2040: National Planning Framework, Dublin: Department of Housing, Planning and Local Government.

Government of Ireland (2018b), Project Ireland 2040: National Development Plan 2018-2027, Dublin: Department of Public Expenditure and Reform.

Grist, B. (2012), An Introduction to Planning Law, Second Edition, Dublin: Institute of Public Administration.

Harvey, B. (2012), Downsizing the Community Sector, Dublin: Irish Congress of Trade Unions.

Hearne, R. (2011), Public Private Partnerships in Ireland: Failed Experiment or Way Forward for the State, Manchester: Manchester University Press.

Hearne, R. and D. Redmond (2014), 'The collapse of PPPs: prospects for social housing regeneration after the crash', in A. MacLaran and S. Kelly (eds), Neoliberal Urban Policy and the Transformation of the City: Reshaping Dublin, Basingstoke: Palgrave Macmillan, pp. 219-232.

Kelly, S. (2014), 'Taking liberties: gentrification as neoliberal urban policy in Dublin', in A. MacLaran and S. Kelly (eds), Neoliberal Urban Policy and the Transformation of the City: Reshaping Dublin, Basingstoke: Palgrave Macmillan, pp. 174-188.

Kitchin, R., J. Gleeson, K. Keaveney and C. O'Callaghan (2010), A Haunted Landscape: Housing and Ghost Estates in Post-Celtic Tiger Ireland, NIRSA Working Paper 59, accessed 24 June 2020 at http://mural.maynoothuniversity.ie/ 2236/1/WP59-A-Haunted-Landscape.pdf.

Kitchin, R., C. O'Callaghan, M. Boyle, J. Gleeson and K. Keaveney (2012), 'Placing neoliberalism: the rise and fall of Ireland's Celtic Tiger', Environment and Planning A, 44 (6), 1302-1326, DOI: 10.1068/a44349.

KPMG (1996), Study on the Renewal Schemes, Dublin: Department of the Environment.

Lennon, M. (2019), 'Planning's position in the "hollowing-out" and "filling-in" of local government in Ireland', Planning Theory and Practice, 20 (4), 612-618, DOI: 10.1080/14649357. 2019.1653003.

Lennon, M., M. Scott and P. Russell(2018), 'Ireland's new National Planning Framework: (re)balancing and (re)conceiving planning for the twenty-first century?', Planning Practice and Research, 33 (5), 491-505, DOI: 10.1080/02697459.2018.1531581.

Lennon, M. and R. Waldron (2019), 'De-democratising the Irish planning system', European Planning Studies, 27 (8), 1607-1625, DOI: 10.1080/09654313.2019.1595532.

Loughlin, J. (2011), 'Ireland: halting steps towards local democracy', in J. Loughlin, F. Hendricks and A. Lidström (eds), The Oxford Handbook of Local and Regional Democracy in Europe, Oxford: Oxford University Press, pp. 48-67.

MacLaran, A., V. Clayton and P. Brudell (2007), Empowering Communities in Disadvantaged Urban Areas: Towards Greater Participation in Irish Urban Planning?, Dublin: Combat Poverty.

MacLaran, A. and L. Murphy (1997), 'The problems of taxation-induced inner-city housing development - Dublin's recipe for success?', Irish Geography, 30 (1), 31-36, DOI: 10.1080/00750779709478646.

Mahon Tribunal (2012), The Final Report of the Tribunal of Inquiry into Certain Planning Matters and Payments, Dublin: Stationery Office.

Moore, N. (1999), 'Rejuvenating docklands: the Irish context', Irish Geography, 32 (2), 135-149.

Moore, N. (2008), Dublin Docklands Reinvented, Dublin: Four Courts Press. 
Moore-Cherry, N. and J. Tomaney (2019), 'Spatial planning, metropolitan governance and territorial politics in Europe: Dublin as a case of metro-phobia?', European Urban and Regional Studies, 26 (4), 365-381.

NESC (National Economic and Social Council) (1979), Urbanisation and Regional Development in Ireland, June 1979, Report number: 45, Dublin: Stationery Office.

NESC (National Economic and Social Council) (1981), Urbanisation: Problems of Growth and Decay in Dublin, Bannon, M. J., Eustace, J. authors, Report number: 55, Dublin: Stationery Office.

Norris, M. (2016), 'Varieties of home ownership: Ireland's transition from a socialised to a marketized policy regime', Housing Studies, 31 (1), 81-101.

Norris, M., M. Gkartzios and D. Coates (2014), 'Property-led urban, town and rural regeneration in Ireland: Positive and perverse outcomes in different spatial and socio-economic contexts', European Planning Studies, 22 (9), 1841-1861, DOI: 10.1080/09654313.2013.806434.

OECD (2018), Subnational Governments in OECD Countries: Key Data, Paris: OECD, accessed 2 June 2020 at www.oecd.org/regional/regional-policy Database: http://dx .doi.org/10.1787/region-data-en.

Payne, D. and P. Stafford (2012), 'Governing the city: institutional innovation and its consequences', in N. Hardiman (ed.), Irish Governance in Crisis, Manchester: Manchester University Press, pp. 158-174.

Quinlivan, A. (2017), 'Reforming local government: must it always be democracy versus efficiency?', Administration, 65 (2), 109-126.

Redmond, D. and M. Norris, (2014), 'Social housing in Ireland', in K. Scanlon, C. Whitehead and M. Fernández Arrigoit (eds), Social Housing in Europe, New York: John Wiley \& Sons, pp. 145-163.

Russell, P. and D. Redmond (2009), 'Social housing regeneration in Dublin: market-based regeneration and the creation of sustainable communities', Local Environment, 14 (7), 635-650.

Watson, D. and E. Corrigan (2019), 'Social housing in the Irish housing market', Economic and Social Review, 50 (1), 213-248.

Williams, B. and I. Boyle (2012), 'The role of property tax incentives in urban regeneration and property market failure in Dublin', Journal of Property Tax Assessment and Administration, 9 (2), 5-21.

Williams, B. and Z. Nedovic-Budic (2016), 'The real estate bubble in Ireland. Policy context and responses', Urban Research and Practice, 9 (2), 204-218, DOI: 10.1080/17535069.2016.1174401.

Williams, B. and P. Sheils (2000), 'Acceleration into sprawl: causes and potential policy responses', Quarterly Economic Commentary, Dublin: Economic and Social Research Institute, pp. 37-73, accessed 12 June 2020 at https://www.esri.ie/system/ files/media/file-uploads/2015-07/QEC2000Jun_SA_Williams.pdf.

Williams, B. and J. Varghese (2018), 'Examining the impact of EU cohesion policies aiming to reduce regional and social disparities with examples of policy impacts in Ireland', Europa XXI, 35, 89-109, http://doi.org/10.7163/Eu21.2018.35.6. 